\title{
Interleukin-10 Modulates Type I Collagen and Matrix Metalloprotease Gene Expression in Cultured Human Skin Fibroblasts
}

\author{
Sakari Reitamo, Anita Remitz, Katsuto Tamai, and Jouni Uitto \\ Departments of Dermatology, and Biochemistry and Molecular Biology, Jefferson Medical College, Section of Molecular Dermatology, \\ Jefferson Institute of Molecular Medicine, Thomas Jefferson University, Philadelphia, Pennsylvania 19107
}

\begin{abstract}
IL-10, originally isolated from mouse helper $\mathbf{T}$ cells, is a cytokine with regulatory functions on a number of interleukins. In this study we show that recombinant human IL-10 affects the expression of several genes involved in extracellular matrix synthesis and remodeling in human dermal fibroblast cultures. As judged by Northern blot analyses, type I collagen gene expression was downregulated, while collagenase and stromelysin gene expression were markedly enhanced by IL-10. No effect on tissue inhibitor of metalloproteases mRNA levels was noted. Transient transfections of skin fibroblasts with type I collagen promoter/chloramphenicol acetyl transferase reporter gene constructs showed downregulation by IL-10, suggesting inhibition at the transcriptional level. When compared with control cultures, incubation with $I L-10$ resulted in a decrease in immunostaining of fibroblast cultures with antibodies to human type I collagen. In contrast, immunostaining of such $\mathrm{IL-10-treated}$ cultures with antibodies to human collagenase resulted in an increase in immunostaining. This study suggests a role for IL-10 in the breakdown and remodeling of the extracellular matrix. (J. Clin. Invest. 1994. 94:2489-2492.) Key words: interleukin-10 - type I collagen • collagenase - stromelysin • fibroblast
\end{abstract}

\section{Introduction}

Interleukin-10 (IL-10) is a $18.5-\mathrm{kD}$ polypeptide which was originally characterized as a cytokine secreted by activated mouse T helper (Th2) ${ }^{1}$ cell clones (1). It inhibits synthesis of several cytokines by $\mathrm{T}$ lymphocytes and activated monocytes and was therefore originally named cytokine synthesis inhibitory factor (1). Specifically, IL-10 suppresses the production of IL- 2 and IFN- $\gamma$, as well as other cytokines by Thl cells and macrophages (1-3). It also inhibits antigen-specific proliferation of Th1 cells (4). In humans, IL-10 is produced, in addition to $T$ cells, by activated monocytes (5), and in contrast to mouse

Address correspondence to Jouni Uitto, M.D., Ph.D., Department of Dermatology, Jefferson Medical College, 233 South 10th Street, Room 450, Philadelphia, PA 19107. 1994.

Received for publication 25 April 1994 and in revised form 3 August

1. Abbreviations used in this paper: AP, activator protein; CAT, chloramphenicol acetyl transferase; GAPDH, glyceraldehyde-3-phosphate dehydrogenase; Th, T helper; TIMP, tissue inhibitor of metalloprotease.

J. Clin. Invest.

(c) The American Society for Clinical Investigation, Inc.

0021-9738/94/12/2489/04 \$2.00

Volume 94, December 1994, 2489-2492
T cells also by various $\mathrm{T}$ cell subsets, including Th0, Th1, and Th2 cell clones $(6,7)$.

The interactions of IL-10 with other cytokines have been studied in considerable detail in human monocytes. For example, IL-10 is a powerful suppressor of the synthesis of IL- $1 \alpha$, IL- $1 \beta$, IL-6, IL-8, TNF- $\alpha$, and granulocyte macrophage and granulocyte colony-stimulating factor by activated monocytes $(4,8)$. Human IL-10 also reduces antigen-specific proliferation of human $\mathrm{T}$ cells (5). Collectively, these previous studies indicate that the effects of IL-10 in monocytes and $T$ cells are mainly downregulatory.

Little information is available on the effects of IL-10 on connective tissue cells. In this study we report that recombinant human IL-10 modulates expression of the genes involved in extracellular matrix synthesis and breakdown in human dermal fibroblasts in vitro.

\section{Methods}

Cell cultures. Adult human skin fibroblast cultures, established from tissue specimens obtained during cosmetic surgery, and neonatal foreskin fibroblast cultures were used in passages 4-10. Cells were maintained in Dulbecco's modified Eagle's medium (DME) supplemented with $10 \%$ FCS, $2 \mathrm{mM}$ glutamine, $50 \mu \mathrm{g} / \mathrm{ml}$ streptomycin, and $50 \mathrm{U} / \mathrm{ml}$ penicillin.

Preparations of IL-10. Recombinant human IL-10 (molecular mass $18.5 \mathrm{kD}$ ) obtained from PeproTech, Inc. (Rocky Hill, NJ) in lyophilized form was dissolved in water, and further dissolved in DME containing $1 \%$ FCS. For cell cultures, IL-10 was used at varying concentrations, ranging from 0.1 to $100 \mathrm{ng} / \mathrm{ml}$.

Northern analyses. Total RNA was isolated from confluent fibroblast cell cultures $(9,10)$ incubated with or without IL-10 in medium supplemented with $1 \%$ FCS for time periods varying from 1 to $24 \mathrm{~h}$. Total RNA, $12 \mu \mathrm{g} / \mathrm{lane}$, was fractionated on $0.8 \%$ agarose gels containing $2.2 \mathrm{M}$ formaldehyde, transferred to nylon filters (Zeta Probe; BioRad Laboratories, Richmond, CA), and immobilized by heating at $80^{\circ} \mathrm{C}$ for $30 \mathrm{~min}$ under vacuum. The filters were prehybridized and hybridized in $50 \%$ formamide, $0.25 \mathrm{M} \mathrm{NaH}_{2} \mathrm{PO}_{4}, \mathrm{pH} 7.2,0.25 \mathrm{M} \mathrm{NaCl}$, $7 \%$ (wt/vol) sodium dodecyl sulphate (SDS), and $1 \mathrm{mM}$ EDTA, using cDNA probes labeled by nick translation with both $\alpha\left[{ }^{32} \mathrm{P}\right] \mathrm{dGTP}$ and $\alpha\left[{ }^{32} \mathrm{P}\right] \mathrm{dCTP}$ (11). After hybridizations at $42^{\circ} \mathrm{C}$ for $18 \mathrm{~h}$, the filters were washed in solutions with decreasing ionic strength and increasing temperature, and the final stringency of the washes was $0.1 \times$ standard saline citrate and $0.1 \%$ SDS, at $65^{\circ} \mathrm{C}$. The radiolabeled cDNA-mRNA hybrids were visualized by autoradiography, and the corresponding steady-state levels of mRNA were quantitated by using a laser densitometer (Ultroscan XL; LKB Instruments, Inc., Bromma, Sweden). The following cDNAs were used for Northern hybridizations: for pro $\alpha 1$ (I) collagen mRNA, a 1.5-kb human cDNA (12); for pro $\alpha 2(\mathrm{I})$ collagen mRNA, a 2.9-kb human cDNA (13); for collagenase, a 2.3-kb human type I collagenase cDNA (14); for stromelysin-1, a 1.8-kb human cDNA (15); for tissue inhibitor of metalloprotease-1 (TIMP-1), a 0.7-kb human cDNA (kindly provided by Dr. D. Carmichael, Synergen, Boulder, $\mathrm{CO}$ ) and a 1.3-kb rat glyceraldehyde-3-phosphate dehydrogenase (GAPDH) cDNA (pRGAPDH13) (16).

Transient transfections of cultured cells. Human foreskin fibroblasts in late logarithmic growth phase were transfected with $10 \mu \mathrm{g}$ of plasmid 


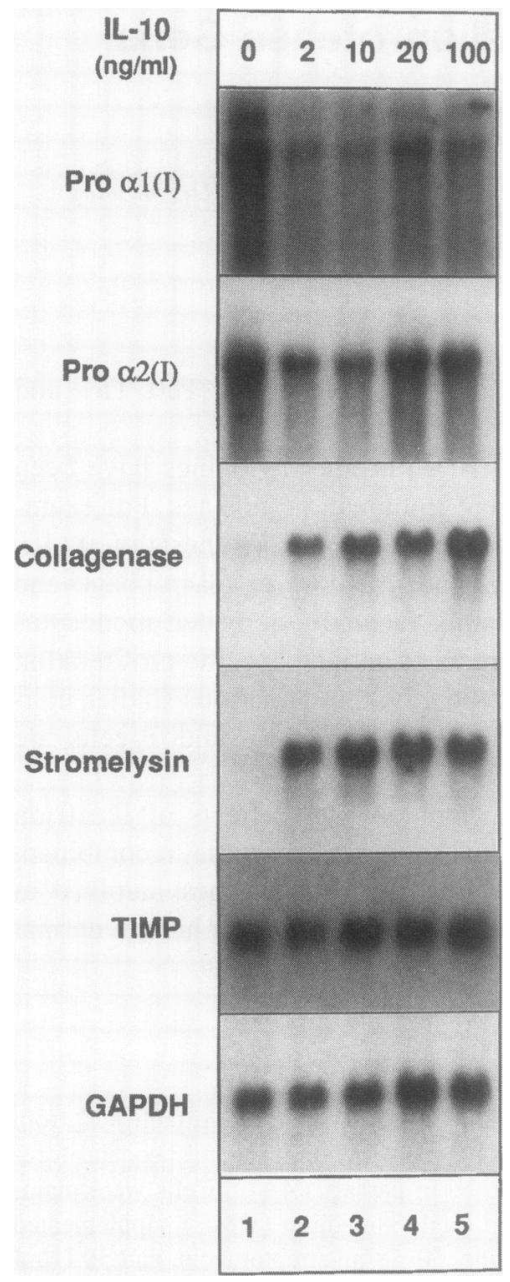

Figure 1. Effect of different concentrations of IL-10 on type I collagen, collagenase, stromelysin, and TIMP mRNA steady-state levels in human skin fibroblasts. Confluent cultures of human skin fibroblasts were incubated with varying concentrations of IL-10 $(0-100 \mathrm{ng} / \mathrm{ml})$ for $24 \mathrm{~h}$ in medium containing $1 \%$ FCS. Total RNA ( 12 $\mu \mathrm{g} /$ lane) was analyzed by Northern blot hybridizations with cDNA probes for determination of mRNAs shown on the left. GAPDH cDNA was used as a control.

DNA (pMS-3.5/CAT), which contains $-3.5 \mathrm{~kb}$ of 5 '-flanking DNA of human pro $\alpha 2(\mathrm{I})$ collagen gene linked to the chloramphenicol acetyl transferase (CAT) reporter gene (17), with $10 \mu \mathrm{g}$ of plasmid DNA pCLCAT3, which contains $-3.8 \mathrm{~kb}$ of 5 '-flanking DNA of human collagenase gene linked to the CAT reporter gene (18), or with the construct pAPCAT2a, which contains three activator protein-1 (AP-1) consensus sequences in front of the thymidine kinase promoter in pBLCAT2 plasmid (18). The transfections were performed with the calcium phosphate/DNA coprecipitation method, followed by $1.5 \mathrm{~min}$ of glycerol shock (15\%) (19). After the glycerol shock, the cells were placed in medium supplemented with $1 \%$ FCS. After $3 \mathrm{~h}$ of incubation, IL-10 was added, and the incubations were continued for $40 \mathrm{~h}$. Parallel transfections were performed with an SV2CAT plasmid. These constructs were cotransfected with an RSV- $\beta$ galactosidase construct for determination of transfection efficiency (11). The cells were then harvested and lysed by three cycles of freeze-thawing in $100 \mu \mathrm{l}$ of $0.25 \mathrm{M}$ Tris-HCl, $\mathrm{pH}$ 7.8. For CAT activity determination, an aliquot of the samples containing the same amount of $\beta$-galactosidase activity was used with $\left[{ }^{14} \mathrm{C}\right]$ chloramphenicol as a substrate, and the acetylated and nonacetylated forms of radioactive chloramphenicol were separated using thin-layer chromatography (11). The CAT activity was determined by the radioactivity in the acetylated forms as a percentage of the total radioactivity of the sample.

Indirect immunofluorescence. The slides containing cultured cells incubated for $36 \mathrm{~h}$ either with or without IL-10 were rinsed with phosphate-buffered saline (PBS) and fixed with ice-cold $100 \%$ ethanol. For detection of type I collagen protein or collagenase protein, after a 30 min incubation with $1 \%$ bovine serum albumin in PBS, the samples were exposed to an affinity-purified rabbit antiserum to human fibroblast collagenase or type I collagen (both kindly provided by Dr. Gregory

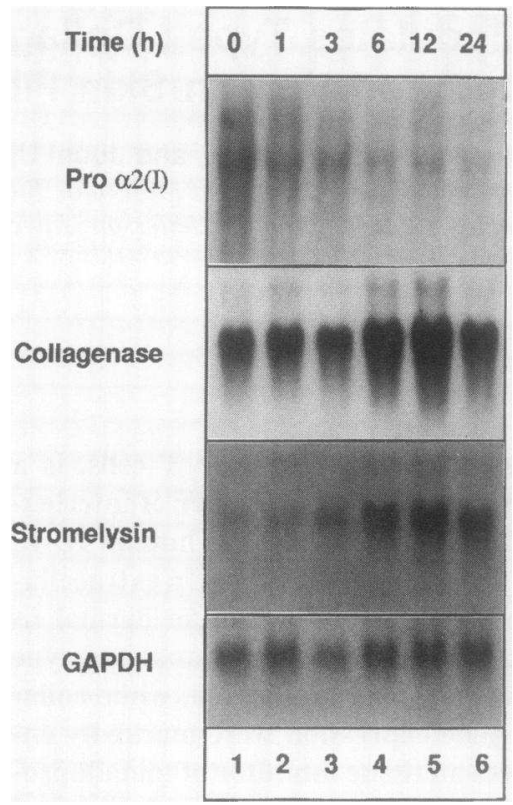

Figure 2. Time course of the effects of IL-10 on pro 2 (I), collagenase, and stromelysin mRNAs in fibroblasts. Confluent cultures of human skin fibroblasts were incubated for various time periods $(0-24 \mathrm{~h})$ with 1 $\mathrm{ng} / \mathrm{ml}$ IL-10 in medium containing $1 \%$ FCS. Total RNA ( $12 \mu \mathrm{g} /$ lane $)$ was analyzed by Northern blot hybridizations with cDNA probes shown on the left.

Goldberg, Washington University School of Medicine, St. Louis, MO) for $45 \mathrm{~min}$ at room temperature. The slides were rinsed with PBS and exposed to rhodamine-conjugated goat anti-rabbit IgG secondary antibodies for $45 \mathrm{~min}$. Nonadherent secondary antibodies were then rinsed off with PBS. Nonspecific labeling was excluded by performing staining with the secondary antibody only, which revealed negative staining reactions.

\section{Results}

IL-10 downregulates type I collagen and upregulates collagenase and stromelysin mRNA steady-state levels. To study the effects of IL-10 on type I collagen, collagenase, and stromelysin, as well as TIMP gene expression at the mRNA level, human skin fibroblast cultures maintained in $1 \%$ FCS were incubated in the presence of IL-10 at concentrations varying from 2 to

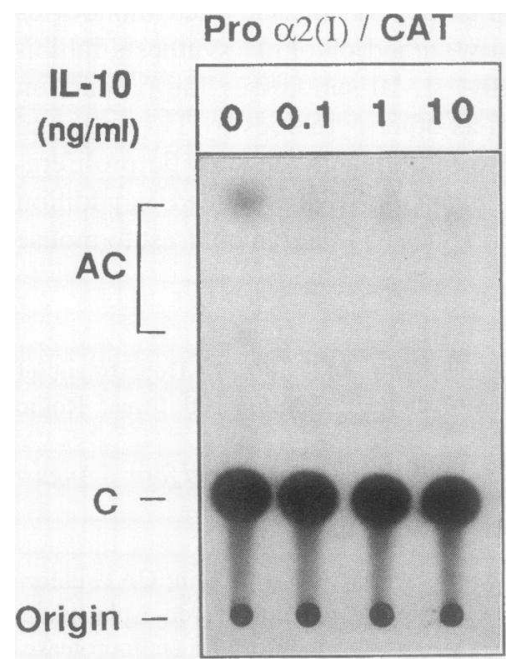

Figure 3. Downregulation of human pro $\alpha 2(\mathrm{I})$ collagen/CAT activity by different concentrations of IL-10 in transient cell transfections. Confluent cultures with human foreskin fibroblasts were transfected with the human pro $\alpha 2$ (I) collagen promoter/CAT reporter gene construct, and CAT activity was determined after $40 \mathrm{~h}$ of incubation with IL-10 in concentrations shown on the top. An autoradiogram of the separation of the acetylated $(A C)$ and nonacetylated $(C)$ forms of $\left[{ }^{14} \mathrm{C}\right]$ chloramphenicol by thin-layer chromatography is shown. Relative promoter activity decreased with IL-10 in concentration $0.1 \mathrm{ng} / \mathrm{ml}$ to $55 \%$, with $1 \mathrm{ng} / \mathrm{ml}$ to $52 \%$, and with $10 \mathrm{ng} / \mathrm{ml}$ to $37 \%$ from the activity noted in untreated cells, respectively. 

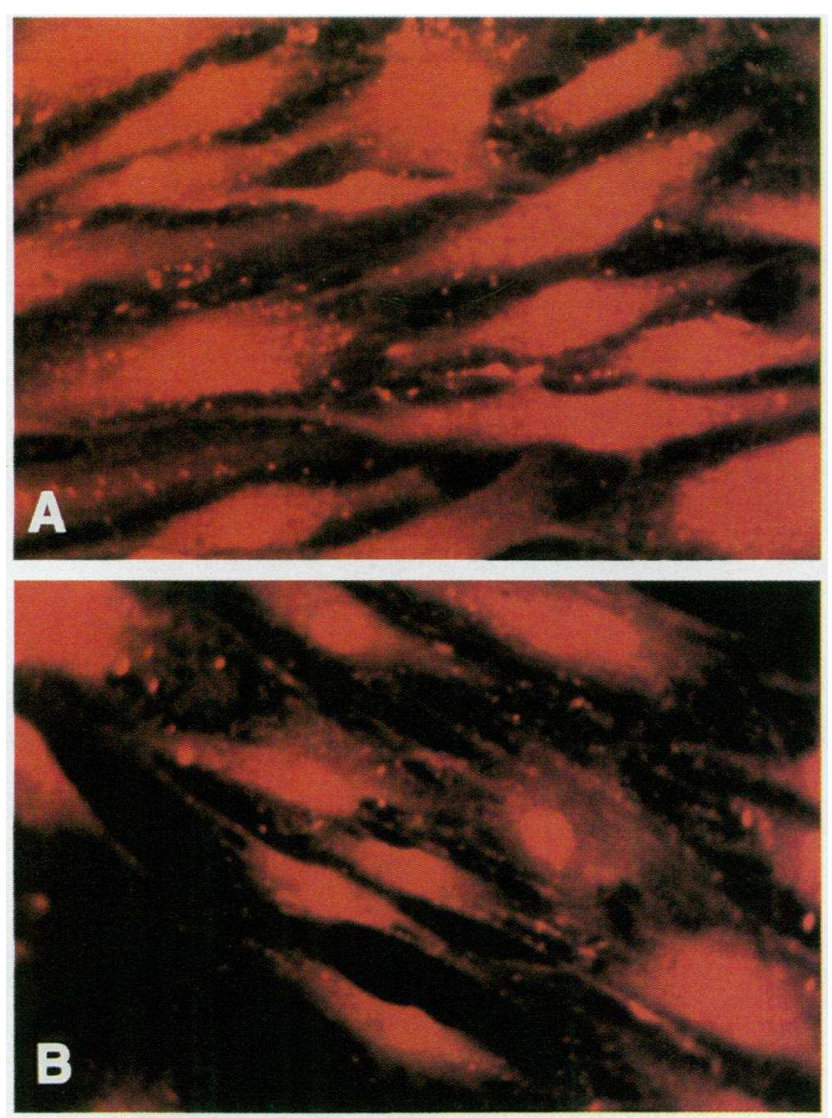

Figure 4. Immunodetection of type I collagen in human skin fibroblasts. Cultures of fibroblasts were incubated without $(A)$ or with IL-10 (1 ng/ $\mathrm{ml})(B)$ for $72 \mathrm{~h}$ in medium containing $1 \%$ FCS. For indirect immunofluorescence, the cells were fixed in cold ethanol before immunolabeling with antibodies to human type I collagen.

$100 \mathrm{ng} / \mathrm{ml}$. As compared with control cultures without IL-10, incubation of the cells with $\mathrm{IL}-10$ resulted in marked downregulation of type I (both pro 1 and pro $\alpha 2$ chain) collagen mRNA steady-state levels (Fig. 1). However, IL-10 caused enhancement of both collagenase and stromelysin mRNA steady-state levels over the wide range of IL-10 concentrations used (Fig. 1). IL-10 had no effect on TIMP gene expression (Fig. 1).

The time course of type I collagen, collagenase, and stromelysin mRNA expression was determined by Northern analysis of fibroblasts exposed to $1 \mathrm{ng} / \mathrm{ml} \mathrm{IL-10} \mathrm{for} \mathrm{different} \mathrm{time} \mathrm{peri-}$ ods. The collagenase and stromelysin mRNA levels showed maximum enhancement after $12 \mathrm{~h}$ of exposure to IL-10, and the levels were reduced at $24 \mathrm{~h}$ (Fig. 2). However, the maximum reduction of type I collagen ( $\alpha 2(\mathrm{I}))$ mRNA levels was seen after $24 \mathrm{~h}$ of exposure (Fig. 2).

Evidence of transcriptional inhibition of type I collagen gene expression by $I L-10$. Transient transfections of human foreskin fibroblasts with a human $\alpha 2$ (I) collagen promoter/ CAT reporter gene construct showed downregulation by IL-10 (Fig. 3), suggesting a transcriptional effect of IL-10 on type I collagen gene expression. In contrast, IL-10 did not modulate the activities of collagenase promoter/CAT reporter gene construct or the construct pAPCAT2a, suggesting that the regulation of collagenase gene expression by IL-10 was not transcriptional and that IL-10 does not affect AP-1 expression. Parallel transfections done with the SV2 promoter/CAT showed no effect of IL-10.
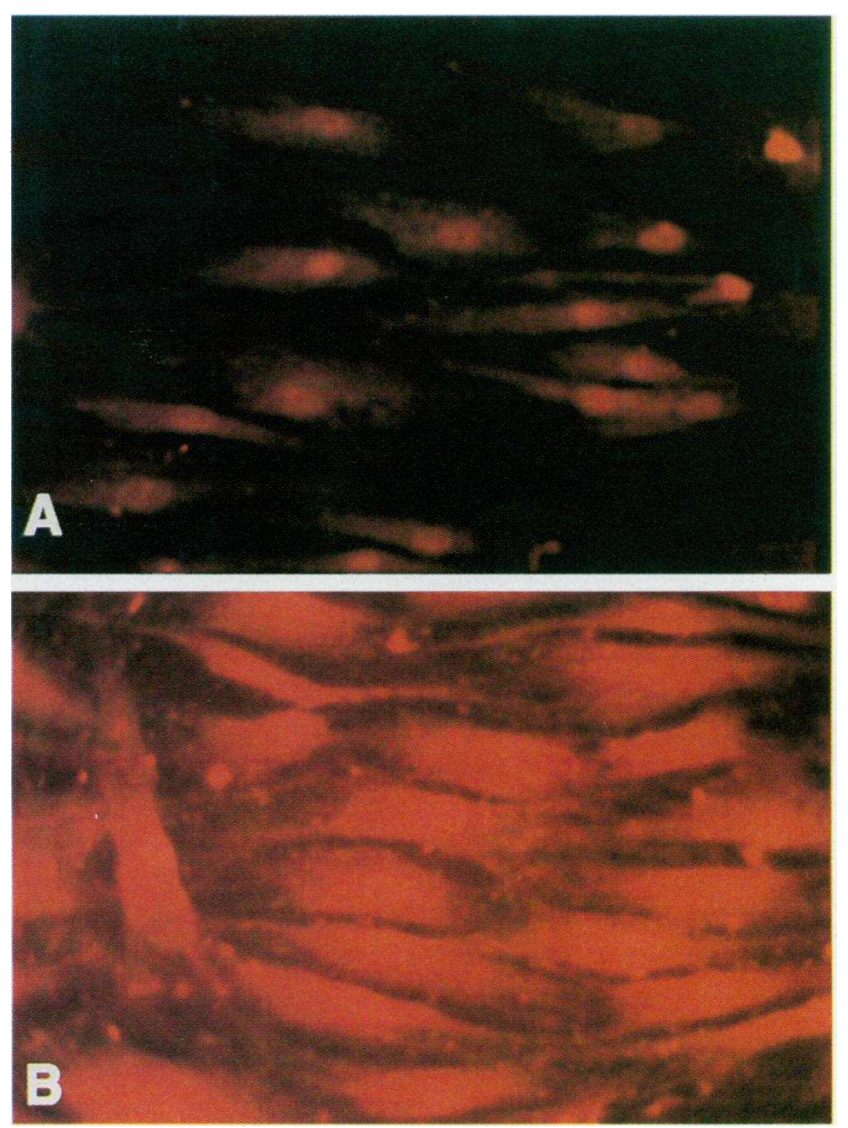

Figure 5. Immunodetection of procollagenase protein in human skin fibroblasts. Cultures of human skin fibroblasts were incubated without $(A)$ or with IL-10 $(1 \mathrm{ng} / \mathrm{ml})(B)$ for $36 \mathrm{~h}$ in medium containing $1 \%$ FCS. Indirect immunofluorescence was performed with antibodies to human procollagenase, as in Fig. 4.

IL-10 reduces type I collagen and increases procollagenase protein in cultured dermal fibroblasts. Human skin fibroblasts in culture have been shown to synthesize precursors of both type I collagen and collagenase proteins which are secreted. To evaluate semiquantitatively the effects of IL-10 on type I collagen and collagenase expression at the protein level, human skin fibroblast cultures maintained in $1 \%$ FCS were incubated in the presence of IL-10 $(1 \mathrm{ng} / \mathrm{ml})$. When compared with control cultures incubated without IL-10, incubation with IL-10 resulted in decreased immunolabeling of cells for type I collagen, suggesting decreased procollagen protein synthesis (Fig. 4). In contrast, immunostaining with an antiserum to human procollagenase resulted in increased immunolabeling for procollagenase protein in human skin fibroblast cultures, suggesting increased procollagenase protein synthesis or decreased breakdown as a result of IL-10 treatment (Fig. 5).

\section{Discussion}

Earlier studies on IL-10 have mainly concentrated on its effects in various immunocompetent cells such as $T$ lymphocytes and monocytes (20). In the present study, we show that IL-10 has additional effects in human dermal fibroblasts. One of these effects is transcriptional inhibition of type I collagen expression. This collagen is the major component of the extracellular matrix in human skin (21). Type I collagen consists of two types of 
polypeptides, namely $\alpha 1$ (I) and $\alpha 2$ (I), and regulation of $\alpha 1$ (I) and $\alpha 2$ (I) expression is coordinate (22). Several responsive elements in the promoter region of these genes have been identified, including NF-1, NF- $\kappa$ B, and AP-2 (23). The effects of IL-10 on type I collagen gene expression could either be due to direct effects on such responsive elements or mediated by effects of IL-10 on other cytokines.

In contrast to type I collagen gene, transient transfections with collagenase reporter gene construct revealed no evidence of transcriptional control of the collagenase gene, suggesting that the observed effects of IL-10 on mRNA steady-state levels could be due to posttranscriptional mechanisms. The collagenase gene contains several AU-rich sequences, which are thought to be involved in posttranscriptional modulation mRNAs (24).

The present findings could have in vivo relevance. While it is not clear whether dermal fibroblasts express IL-10, there are cells in normal skin capable of IL-10 expression and secretion. As shown recently by Enk and Katz (25), murine keratinocytes secrete IL-10 when appropriately stimulated. An in vivo situation in which IL-10 induction could play a role is the exposure to ultraviolet (UV) radiation. Such an exposure has been shown to result in impairment of delayed type hypersensitivity which has been shown to be at least in part mediated by IL-10 (26). Chronic exposure to UV leads additionally to changes in the composition of the matrix molecules, mainly to a decrease in the amount of collagen and an increase in the amount of elastic fibers in the dermis. Induction of collagenase and stromelysin in vivo would result in a decrease of type I collagen, which is the main component of the dermis. This study shows, however, that IL-10 has an effect on type I collagen gene expression. Of interest, we have shown recently that, in a transgenic mouse model transfected with a human elastin promoter/CAT construct, IL-10 induces the elastin promoter activity in dermal fibroblasts (27). Taken together, these results suggest that IL10 may be involved in the pathogenesis of UV-induced changes in the dermis.

In conclusion, IL-10, among several other cytokines such as IL- 1 , TNF- $\alpha$, and TGF- $\beta$, is probably involved in the regulation of type I collagen synthesis and degradation.

\section{Acknowledgments}

We wish to thank Lin Lin for technical assistance. Dr. John Moore and Dr. James Fox provided tissue for cell cultures. Dr. Lidia Rudnicka performed the immunostaining.

This study was supported by the United States Public Health Service, National Institutes of Health grant RO1-AR41439, the Academy of Finland, and Finska Läkaresällskapet. Dr. Reitamo was a recipient of a Fellowship from the Jefferson Center for International Dermatology at Jefferson Medical College.

\section{References}

1. Fiorentino, D. F., M. W. Bond, and T. R. Mosmann. 1989. Two types of mouse $T$ helper cell. IV. Th2 clones secrete a factor that inhibits cytokine production by Th1 clones. J. Exp. Med. 170:2081-2095.

2. Viera, P., R. de Waal Malefyt, M.-N. Dang, K. E. Johnson, R. Kastelein, D. F. Fiorentino, J. E. de Vries, M.-G. Roncarolo, T. R. Mosmann, and K. W. Moore. 1991. Isolation and expression of human cytokine synthesis inhibitory factor cDNA clones: homology to Epstein-Barr virus open reading frame BCRFI. Proc. Natl. Acad. Sci. USA. 88:1172-1176.
3. de Waal Malefyt, R., H. Yssel, and J. E. de Vries. 1993. Direct effects of IL-10 on subsets of human CD4 ${ }^{+} \mathrm{T}$ cell clones and resting $\mathrm{T}$ cells. Specific inhibition of IL-2 production and proliferation. J. Immunol. 150:4754-4765.

4. de Waal Malefyt, R., J. Haanen, H. Spits, M.-G. Roncarolo, A. te Velde, C. Figdor, K. Johnson, R. Kastelein, H. Yssel, and J. E. de Vries. 1991. Interleukin 10 (IL-10) and viral IL-10 strongly reduce antigen-specific human T cell proliferation by diminishing the antigen-presenting capacity of monocytes via downregulation of class II major histocompatibility complex expression. J. Exp. Med. 174:915-924.

5. de Waal Malefyt, R., J. Abrams, B. Bennett, C. G. Figdor, and J. E. de Vries. 1991. Interleukin 10 (IL-10) inhibits cytokine synthesis by human monocytes: an autoregulatory role of IL-10 produced by monocytes. J. Exp. Med. 174:12091220.

6. Yssel, H., R. de Waal Malefyt, M.-G. Roncarolo, J. S. Abrams, R. Lahesmaa, H. Spits, and J. E. de Vries. 1992. IL-10 is produced by subsets of human $\mathrm{CD}^{+} \mathrm{T}$ cell clones and peripheral blood T cells. J. Immunol. 149:2378-2384.

7. Del Prete, G., M. de Carli, F. Almerigogna, M. G. Giudizi, R. Biagiotti, and S. Romagnani. 1993. Human IL-10 is produced by both type 1 helper (Th1) and type 2 helper (Th2) T cell clones and inhibits their antigen-specific proliferation and cytokine production. J. Immunol. 150:353-360.

8. Fiorentino, D. F., A. Zlotnik, P. Viera, T. R. Mosmann, M. Howard, K. W. Moore, and A. O'Garra. 1991. IL-10 acts on the antigen-presenting cell to inhibit cytokine production by Th1 cells. J. Immunol. 146:3444-3451.

9. Chirgwin, J. M., A. E. Przybyla, R. J. MacDonald, and W. J. Rutter. 1979. Isolation of biologically active ribonucleic acid from sources enriched in ribonuclease. Biochemistry. 18:5294-5299.

10. Thomas, P. S. 1980. Hybridization of denatured RNA and small DNA fragments transferred to nitrocellulose. Proc. Natl. Acad. Sci. USA. 77:52015205.

11. Sambrook, J., E. F. Fritsch, and T. Maniatis. 1989. Molecular Cloning: A Laboratory Manual. 2nd ed. Cold Spring Harbor Laboratories, Cold Spring Harbor, NY.

12. Chu, M.-L., J. C. Myers, M. P. Bernard, J.-F. Ding, and F. Ramirez. 1982. Cloning and characterization of five overlapping cDNAs specific for the human pro alpha1 (I) collagen chain. Nucleic Acids Res. 10:5925-5934.

13. Myers, J. C., M.-L. Chu, S. H. Faro, W. J. Clark, D. J. Prockop, and F. Ramirez. 1981. Cloning of cDNA for the pro alpha 2 chain of human type I collagen. Proc. Natl. Acad. Sci. USA. 28:3516-3520.

14. Goldberg, G. I., S. M. Wilhelm, A. Kronberger, E. A. Bauer, G. A. Grant, and A. Z. Eisen. 1986. Human fibroblast collagenase. Complete primary structure and homology to an oncogene transformation-induced rat protein. J. Biol. Chem. 261:6600-6605.

15. Saus, J., S. Quinones, Y. Otani, H. Nagase, E. D. Harris, Jr., and M. Kurkinen. 1988. The complete primary structure of human matrix metalloproteinase-3. J. Biol. Chem. 263:6742-6745.

16. Fort, P., L. Marty, M. Piechaczyk, S. El Sabrouty, C. Danz, P. Jeanteur, and J. M. Blanchard. 1985. Various rat adult tissues express only one major mRNA species from the glyceraldehyde-3-phosphate-dehydrogenase multigenic family. Nucleic Acids Res. 13:1431-1442.

17. Boast, S., M.-W. Su, F. Ramirez, M. Sanchez, and E. V. Avvedimento. 1990. Functional analysis of cis-acting DNA sequences controlling transcription of the human type I collagen genes. J. Biol. Chem. 265:13351-13356.

18. Frisch, S. M., R. Reich, I. E. Collier, L. T. Genrich, G. Martin, and G. I. Goldberg. 1990. Adenovirus E1A represses protease gene expression and inhibits metastasis of the tumor cells. Oncogene. 5:75-83.

19. Graham, F. L., and A. J. van der Eb. 1973. Transformation of rat cells by DNA of human adenovirus 5. Virology. 54:536-539.

20. Howard, M., and A. O'Garra. 1992. Biological properties of interleukin 10. Immunol. Today. 13:198-200.

21. Chu, M.-L., and D. J. Prockop. 1993. Collagen: gene structure. In Connective Tissue and Its Heritable Disorders. Wiley-Liss, Inc., New York. 149-165.

22. Pogulis, R. J., and S. O. Freytag. 1993. Contribution of specific cis-acting elements to activity of the mouse pro- $\alpha 2$ (I) collagen enhancer. J. Biol. Chem. 268:2493-2499.

23. Slack, J. L., D. J. Liska, and P. Bornstein. 1993. Regulation of expression of the type I collagen genes. Am. J. Med. Genet. 45:140-151.

24. Shaw, G., and R. Kamen. 1986. A conserved AU sequence from the $3^{\prime}$ untranslated region of the GM-CSF mRNA mediates selective mRNA degradation. Cell. 46:659-667.

25. Enk, A. H., and S. I. Katz. 1992. Identification and induction of keratinocyte-derived IL-10. J. Immunol. 149:92-95.

26. Rivas, J. M., and S. E. Ullrich. 1992. Systemic suppression of delayed-type hypersensitivity by supernatants from UV-irradiated keratinocytes. J. Immunol. 149:3865-3871.

27. Reitamo, S., A. Remitz, K. Tamai, and J. Uitto. 1994. Interleukin 10 upregulates elastin gene expression in vivo and in vitro at the transcriptional level. Biochem. J. 302:331-333. 